\title{
O Admirável Projeto Genoma Humano
}

\author{
MARILENA V. CORRÊA
}

\section{RESUMO}

Este artigo apresenta um panorama das implicações sociais, éticas e legais do Projeto Genoma Humano. Os benefícios desse megaprojeto, traduzidos em promessas de uma revolução terapêutica na medicina, não se realizarão sem conflitos. O processo de inovação tecnológica na genética traz problemas de ordens diversas: por um lado, pesquisas em consórcio, patenteamento de genes e produtos da genômica apontam interesses comerciais e dificuldades de gerenciamento dos resultados dessas pesquisas. Esses problemas colocam desafios em termos de uma possível desigualdade no acesso aos benefícios das pesquisas. Por outro lado, temos a questão da informação genética e da proteção de dados individuais sobre riscos e suscetibilidades a doenças e atributos humanos. O problema da definição de homens e mulheres em função de traços genéticos traz uma ameaça discriminatória clara, e se torna agudo em função do reducionismo genético que a mídia ajuda a propagar. As respostas a esses problemas não podem ser esperadas apenas da bioética. A abordagem bioética deve poder combinar-se a análises políticas da reprodução, da sexualidade, da saúde e da medicina. Um vastíssimo espectro de problemas como estes não pode ser discutido em profundidade em um artigo. Optou-se por mapeá-los no sentido de enfatizar em que medida, na reflexão sobre o projeto genoma, a genômica e a pós-genômica, enfrenta-se o desafio de articular aspectos tão diferenciados.

Palavras-chave: Projeto Genoma Humano; inovação genética; reprodução; bioética. 
Marilena V. Corrêa

\section{Introdução}

A genética e os desdobramentos do Projeto Genoma Humano, em termos de pesquisas ou de produtos, vêm sendo construídos como um dos principais campos de inovações biotecnológicas. A possibilidade de incorporação dessas inovações pela medicina representaria um salto de qualidade: com a genética teríamos uma busca mais profunda das causas de doenças, testes de diagnóstico mais específicos, terapêuticas mais eficazes, enfim mais e mais. Essa perspectiva constitui, na verdade, aquilo com que se justifica qualquer projeto de pesquisa em qualquer área do desenvolvimento médicocientífico. Para além dos benefícios que, por motivos a serem analisados, são atribuídos às inovações genéticas, há a otimista conotação da capacidade de promoção do surgimento de um novo mundo, de um outro mundo, talvez de um outro homem desenhado pela medicina do amanhã. Para o público em geral, o único limite possível para esse admirável mundo novo parece ser, tal como no livro de Huxley, apenas os limites éticos.

É possível dizer que um primeiro benefício esperado do Projeto Genoma Humano seria, em tese, a diminuição do sofrimento humano, pela ampliação das possibilidades de diagnóstico e cura de doenças. Essa perspectiva tem, em muitos casos, justificado a realização de projetos de pesquisa concretos, o que caracteriza o conseqüencialismo e o utilitarismo dominantes na análise bioética. Mas a contrapartida dos problemas que aquele projeto comporta anuncia-se de imediato:: engenharia ou desenho de embriões humanos, comodificação de seres humanos, intervenções na reprodução humana, busca de aperfeiçoamento de características humanas e eugenia, discriminação de base genética, genética comportamental, patenteamento de genes, injustiça na distribuição de recursos, pela exclusão econômica de usuários de possíveis produtos de pesquisa (como as terapias genéticas), ameaça à privacidade individual, pela violação da confidencialidade de informações genéticas, entre tantos outros problemas. Princípios tradicionais da bioética beneficência, não-maleficência, autonomia, justiça - para se concretizarem, no Projeto Genoma Humano, deverão fazer face a profundos conflitos de ordem moral, dadas as controvérsias que o uso da informação genética é capaz de gerar.

A abordagem pontual de um ou outro daqueles aspectos tem constituído objeto das ciências humanas e sociais aplicadas à saúde. Levando-se em conta categorias como indivíduo, doença, saúde e sociedade, a genômica 
pode ser um caso modelar de estudos para a saúde coletiva, pela forma como as inovações são produzidas e como elas vêm sendo socialmente recebidas e construídas. Por se tratar de um campo de reflexão em plena construção, decidimos privilegiar, neste artigo, uma apresentação informativa. Procuramos fornecer elementos de modo a evidenciar a rede de fatores em jogo nas inovações genômicas e sua apropriação pela bioética. A partir dá, alguns pontos são destacados, o que nos permite fazer face ao imaginário quase messiânico que conota as pesquisas genéticas como "revolucionárias", "milagrosas". Em um artigo seguinte, algumas questões mapeadas ao longo deste texto deverão receber tratamento analítico e argumentativo, que não pode ser realizado aqui.

\section{Os Projetos Genoma - Algumas Informações}

Uma diferenciação se faz necessária entre genética clássica ou mendeliana e a nova genética, porque muito do que se discute hoje em termos de implicações éticas, sociais e políticas dos usos e aplicações da informação genética, seu possível impacto na vida cotidiana de homens e mulheres, está ligado a uma nova forma de conhecimento genético gerado, em particular, pelo Projeto Genoma Humano.

De maneira bastante esquemática: 1) a genética mendeliana ou clássica é aquela que estuda a correlação entre um único gene e um traço (cor dos olhos, por exemplo) ou uma doença (monogênica). O conhecimento produzido pela genética mendeliana aplicada ao homem seguiu-se a estudos que utilizavam modelos animais ou vegetais, de análise do padrão de transmissão de traços herdados. Entre humanos, esse conhecimento segue a análise do padrão familiar de repetição daqueles aspectos ${ }^{2}$. 2) A genômica, por sua vez, é o estudo direto de genes, de suas funções e interações simultâneas. Além das doenças monogenéticas, ela tem como objeto traços e doenças poligênicas e multifatoriais, que envolvem a interação entre diferentes genes e destes com fatores ambientais não-genéticos.

Um marco fundamental na nova genética é o Projeto Genoma Humano (PGH). O PGH é um consórcio internacional de pesquisas liderado pelos Estados Unidos que se iniciou em $1990^{3}$. Embora se fale de um projeto globalizado, os Estados Unidos participam com dois terços da pesquisa; Inglaterra, França, Alemanha, Canadá e Japão com quase todo o restante de projetos, sendo pouco significativa a participação de outros países. Nesse consórcio, os dados são tornados públicos e os resultados parciais - as 
seqüências genéticas - são disponibilizadas rapidamente por via eletrônica. Em conseqüência, diferentemente do que se passa em outras pesquisas, não se patentearia nem se reteria em segredo a informação produzida durante etapas intermediárias de pesquisa - basicamente, informação sobre seqüências de genes humanos. Foram desenvolvidos métodos automatizados de seqüenciamento de genes e sua aplicação resultou no surgimento e rápido crescimento de uma disciplina - a bioinformática, que é muito mais que um suporte à genômica. Os projetos genomas - humano ou não - e outros projetos nessa área são, hoje, dependentes de técnicas e métodos informatizados.

Como se tornou conhecido e divulgado, a saída de um dos coordenadores do PGH para criar uma empresa privada, voltada também para o seqüenciamento do genoma humano, instalou uma competição que, entre outras conseqüências, acabou por encurtar o prazo previsto de finalização do projeto. A finalização do seqüenciamento do genoma foi atribuída a ambos, consórcio público e empresa privada (a Celera Genomics), em junho de 2000 (Davies, 2001).

O Brasil, assim como outros países em desenvolvimento, mesmo contando com infra-estrutura de pesquisa que justificaria sua participação, esteve totalmente excluído do PGH. Como reação, esses países chegaram a constituir uma organização - o Programa Latino-Americano do Genoma Humano - formada por cientistas e empresas de biotecnologia cuja preocupação inicial era garantir aos pesquisadores excluídos acesso aos dados produzidos pelo projeto "global" $\mathrm{PGH}$, e uma forma de resistência ao biocolonialismo daquele megaprojeto (Oliveira, 1997).

Paralelamente e de forma independente do PGH, por iniciativa e coordenação da Fapesp e do Instituto Ludwig de Pesquisas sobre Câncer (uma instituição internacional), desenvolveu-se, no Brasil, o Projeto Genoma do Câncer, que já seqüenciou cerca de um milhão de genes de células tumorais. A seguir, em 2001, foi lançado o Projeto Genoma Clínico, também sob a forma de consórcio, envolvendo 19 equipes de pesquisadores e voltado para o estudo diagnóstico e tratamento de alguns cânceres ${ }^{4}$. Os dois projetos brasileiros têm tido grande repercussão internacional, revertendo assim, em parte, sua posição dominada e excluída no cenário do PGH.

No início do PGH, em 1990, foram estimados gastos totais da ordem de três bilhões de dólares para o seqüenciamento de genes humanos. Parte destes, entre 3 e $5 \%$ dos gastos anuais, deveria vir a ser alocada em programas de pesquisas no campo social e da ética, segundo diretiva do 
Conselho Consultivo do PGH, conhecido como HUGO (Human Genome Organization). Esse percentual representa um volume de recursos jamais destinado para estudos bioéticos ou pesquisas socioantropológicas sobre a inovação biotecnológica. Pode-se avaliar, pela mesma razão, a enormidade dos problemas éticos e sociais antevistos nos estudos genéticos a partir do PGH.

Essa linha de investigação dentro do PGH ficou conhecida como ELSI Program (Ethical, Legal and Social Implications of the Human Genome Project). Centralizado junto à coordenação americana do $\mathrm{PGH}$, o Programa ELSI adota uma orientação específica. Ele visa a algo como uma alfabetização bioética sobre a pesquisa do genoma e as possíveis intervenções genéticas sobre seres humanos. Seu objetivo principal é o treinamento de alto nível de professores e pesquisadores universitários, oriundos tanto das ciências humanas como das biomédicas, capazes de reproduzir para estudantes de graduação os conteúdos e a forma de problematização, pelo menos em linhas gerais, propostos pela coordenação central do PGH. O Programa ELSI é, nesse sentido, uma aculturação da pesquisa e inovações genéticas:

"This program was geared towards multidisciplinary faculty from liberal arts colleges and universities with an interest in learning how to effectively teach an ELSI course at their home institutions (...) how to train teachers to teach the ELSI of genetic research", .

Talvez este seja o mais importante subprojeto do PGH, uma vez que discute problemas gerados a partir de todos os outros subprojetos derivados do PGH, como os estudos do câncer, o Projeto Genoma da Diversidade Humana, a genética comportamental, entre outros. O PGH parece, portanto, promover esse novo ethos científico, no qual a produção de conhecimento e a biotecnologia seriam indissociáveis de uma permanente vigilância ética.

\section{Redes de Inovação e Genética}

Os projetos na área genômica têm sido desenvolvidos sob a forma peculiar de consórcios ou redes de pesquisa. O interesse de uma análise socioantropológica da inovação genética e de outros objetos técnicos na área biomédica se deve à sua natureza híbrida, ao mesmo tempo técnica e social. $\mathrm{E}$, também, à particularmente intensa colaboração entre pesquisa pública e privada na produção de inovações biotecnológicas (Cassier e Gaudillière, 2000a, 2000b; Cassier, 2000; Cassier, 1998; Hogle, 2000; Julian-Reyner et 
al.,1996; Latour, 1989) ${ }^{6}$.

Para o seqüenciamento de genes humanos no PGH - e em outros projetos, como o genoma da levedura, o consórcio europeu de seqüenciamento de genes de predisposição ao câncer de mama -, ficou estabelecido que seria indispensável a colaboração entre universidades e laboratórios públicos, empresas privadas de biotecnologia, laboratórios farmacêuticos, sob a forma de consórcio.

“As vantagens econômicas da pesquisa em consórcio são múltiplas: permitem dividir os custos e riscos de pesquisa e desenvolvimento $\mathrm{P} \& \mathrm{D}$, reduzir volumes de investimentos, reunir competências complementares para criar novos conhecimentos ou técnicas, gerar conhecimentos novos pela reunião de coleção de amostras privadas e dispersas" (Cassier, 1998, p. 74).

A colaboração e transferência de tecnologia entre universidade e empresa já eram uma realidade antes da disseminação da pesquisa em consórcio, ocupando amplos espaços na área da biotecnologia. Regras e contratos estabelecidos entre as instituições definiam os direitos de propriedade intelectual sobre os resultados em moldes tradicionais de patentes e segredo industrial. $\mathrm{O}$ problema da dependência da universidade em relação à empresa privada é particularmente crítico, em especial para países não-centrais, como o Brasil.

No caso da biotecnologia e da genômica em particular, um mercado privado da pesquisa não pára de crescer, ligado, sem dúvida, à proporção dos interesses econômicos incorporados e vislumbrados. O mercado da genômica, que inclui desde dispositivos como kits diagnósticos a equipamentos de infraestrutura, como seqüenciadores de DNA, entre outros objetos técnicos, prenuncia a movimentação de somas extraordinárias. Uma empresa de consultoria americana avaliou, em 1999, que o potencial comercial da pesquisa genômica para os Estados Unidos, em termos de venda de produtos e tecnologia de DNA, atingiria 45 bilhões de dólares em $2009^{7}$, o que indica a disputa hoje instalada nesse setor industrial e comercial. Mas não apenas empresas privadas realizam investimentos nessa área. Em 1997, 36\% dos pedidos de patente na área da genética nos Estados Unidos foram feitos pelos National Institutes of Health que desenvolvem pesquisas com fundos públicos (Cassier, 2000, p. 26).

$\mathrm{Na}$ pesquisa em consórcio, as empresas de biotecnologia são apenas em parte concorrentes das públicas, mantendo ligações estreitas com as instituições universitárias. Em conseqüência, particularidades em termos de novas 
formas de gestão de dados e resultados de pesquisa, bem como do relacionamento entre pesquisadores e instituições, sobressaem dessas experiências. As trocas de informações e de material entre pesquisadores, antes baseadas na confiança e reciprocidade, passam a ser objeto de acordos complexos, visando à exploração de direitos no futuro (Cassier, 2000, p. 27-28). A mobilidade dos pesquisadores para o setor privado é parte do processo de transferência de tecnologia. Na mudança entre uma e outra empresa (da pública para privada ou vice-versa), o saber incorporado à pessoa do pesquisador é "transferido" com ele. Com muita freqüência, nesse processo, o pesquisador vem a ser sócio ou fundador de uma nova empresa de biotecnologia ${ }^{8}$. A coexistência é tão grande que empresas privadas costumam localizar-se fisicamente próximas às grandes universidades (lembramos, por exemplo, a enorme concentração de empresas de biotecnologia na região da cidade de Boston, nos Estados Unidos) ${ }^{9}$.

Além daqueles aspectos, características próprias ao objeto favorecem pesquisas em rede. É o caso dos genomas, cuja divisibilidade permite que diferentes laboratórios participem do seqüenciamento de partes do DNA (Cassier, 1998, p. 75). É o caso também do estudo de genes de predisposição de doenças, ilustrado pelo consórcio público europeu do câncer de mama. Ele permite constituir bancos de dados biológicos (amostras de DNA) e médicos (genealogias e histórias familiares detalhadas), a partir de diferentes fontes, como laboratórios e serviços médicos. A instituição de serviços médicos, com a prestação de serviços é, portanto, outro elemento central nas redes de inovação da pesquisa genômica. As consultas de oncogenética são uma inovação dessa pesquisa e representam, além de um espaço terapêutico, uma fonte e um locus (o serviço médico) de centralização, em bancos de dados genéticos sobre famílias que vão alimentar a pesquisa sobre cânceres de incidência familiar (Julian-Reyner et al., 1996).

Algumas dificuldades específicas ressaltam dessa forma de colaboração. Como apontado por Cassier (2000), o fato de um pesquisador sair ou mudar de laboratório, o desequilíbrio em termos do financiamento entre, por um lado, a face pública e acadêmica da pesquisa e a privada, e, por outro, desentendimentos sobre prazos e restrições para publicação e comunicação dos resultados são fontes importantes de conflito. Pontos particularmente críticos no consórcio de pesquisa seriam a necessidade de convergência técnica e a proteção à informação (Cassier 1998, p. 27). A pesquisa em consórcio impõe uma definição de interfaces técnicas e de coordenação entre equipes e centros que implica um controle e padronização dos dados 
de cada unidade participante do consórcio para que, no processo de seqüenciamento e ao final, "as partes - seqüências - se soldem".

Mas o ponto mais sensível na colaboração entre pesquisa pública e privada nos consórcios biotecnológicos é a proteção da informação. A apropriação e a circulação dos resultados implicam a criação de novas formas de gerência que respondam: a quem pertencem os direitos de propriedade intelectual, sobre que informações, quais delas são de domínio público, em que momento divulgar dados, publicar etc. A discussão técnica sobre esse ponto, apesar de muito importante, é longa e não constitui o foco deste artigo.

Mas além de técnico, o problema dos direitos de propriedade intelectual na área da genômica interessa de forma central à bioética, independentemente de a pesquisa ser realizada em consórcio (Cook-Degan, 1997; Eisenberg, 1992; Hanson, 1997; McGee, 1998; Merz e Cho, 1998). Discute-se se seqüências genéticas, os genes, deveriam ser patenteados ou se caberia patentear apenas aplicações médicas bem definidas. O gene poderia ser considerado uma invenção? De acordo com as leis brasileiras, sendo parte do organismo, o DNA não poderia ser objeto de patente, assim como outras substâncias naturais. Seu patenteamento exigiria agregar à descoberta de genes uma aplicação inventiva, não óbvia e úti1 ${ }^{10}$. Editorial da Folha de São Paulo sobre o assunto $(2000)^{11}$, compara a patente de genes ao hipotético patenteamento de elementos químicos. O detentor da patente do carbono, por exemplo, tornar-se-ia proprietário do direito de explorar praticamente todas as drogas.

Apesar da existência de uma Declaração Universal do Genoma Humano e dos Direitos Humanos (Unesco, 1997) - indicando ser o genoma patrimônio da Humanidade e a não-patenteabilidade de genes humanos - a proteção da informação sobre o genoma tem-se mostrado na prática, não apenas limitada mas também vulnerável aos interesses do mercado biotecnológico ${ }^{12}$. São inúmeros os casos de patenteamento de seqüências genéticas, em particular nos Estados Unidos, questionáveis do ponto de vista técnico, nos quais, em função de seu tipo e extensão, por exemplo, a patente pode provocar o bloqueio de novas pesquisas sobre o mesmo problema.

Um exemplo bastante discutido na literatura bioética é o caso dos genes BRCA1 e BRCA2 (Carneiro e Bartholo, 1999; Geller et al, 1997; Goelen et al. 1999; Koenig et al., 1998; Rothenberg, 1997). Em 1994, após mais de dez anos de pesquisa em diferentes centros do mundo, a mutação de um gene (BRCA1) relacionado à predisposição a um certo tipo de câncer de mama e, menos freqüentemente, ao de ovário, foi clonada e seqüenciada. 
Ao final de uma guerra por patentes e operações de compra de direitos, aquele resultado técnico (o seqüenciamento) foi adquirido por uma empresa de biotecnologia norte-americana, Myriad Genetics, associada a uma indústria farmacêutica, a Eli Lilly. Em 1998, aquela empresa conseguiu um extenso monopólio, que cobre: "a reprodução da seqüência de DNA (o gene), produtos derivados, como sondas, animais transgênicos, anticorpos, genes mutantes, todos os métodos diagnósticos de predisposição ao câncer de mama ou de ovários, assim como as aplicações terapêuticas e de screening" (Cassier, 2000b).

Assim, como esse gene sofre muitas mutações, a Myriad é a única empresa autorizada a pesquisar novas mutações, nos Estados Unidos. Como única "proprietária" do gene, ela é a única a poder explorar comercialmente quaisquer novos testes genéticos de predisposição a aqueles cânceres. Altamente problemático ainda, de um ponto de vista bioético, é o fato de esse mercado de testes autonomizar-se do contexto médico. Além de comercializar diretamente testes a clientes, via oferta pela internet por exemplo, a empresa realiza testagem "apoiada" por seguradoras de saúde e de vida. Estas pagam pelos exames de sua clientela para conhecer os resultados de um suposto risco genético (Cassier e Gaudillière 2000b, p. 28). Através dos acordos firmados com seguradoras, a empresa de biotecnologia assegura uma clientela nesse mercado já monopolizado.

\section{A Lente da Genética}

O conhecimento do genoma humano vem sendo socialmente construído como aquele que traçará o mapa da vida, decifrará seus mistérios, possibilitará a escritura do livro do homem, sendo o próprio genoma referido como $o$ programa, código dos códigos, entre outras metáforas espetaculares, quase messiânicas, encontradas nesse campo.

Do ponto de vista técnico, antecipa-se um horizonte de benefícios: 1) descoberta de causas de doenças, testes diagnósticos precisos, regimes terapêuticos eficazes, como a terapia genética ou a farmacogenômica; 2) maior monitoramento ambiental e controle de substâncias tóxicas, químicas ou biológicas, à medida que se desvendam interações patogênicas entre essas substâncias e os genes, na determinação de doenças; 3) ampliação da avaliação de risco, pela análise de variações na resistência (genética) àqueles agentes; 4) estudo genético da diversidade humana - bioarqueologia, evolução e migração de grupos populacionais; 5) aplicações forenses de 
análise do DNA com fins identificatórios. Mesmo diante dessa antevisão de benefícios, pairam suspeitas quanto às ameaças que a informação genética e a intervenção de base genética possam vir a representar para os indivíduos, o que fez proliferar o debate bioético em torno daqueles benefícios potenciais.

Textos especializados, artigos críticos e matérias jornalísticas reforçam a idéia de que a informação genética seria capaz de alterar visões sobre o mundo, visões que as pessoas têm de si mesmas e dos outros. Arthur Kaplan, diretor do Centro de Bioética da Universidade da Pensilvânia, fala em uma "revolução intelectual" capaz de "afetar nossas vidas cotidianas". Lori Knowles, bioeticista do Hasting Center, lembra que o tipo de certeza que o enfoque genético produz é bastante perigoso, porque é feito às custas de um abandono do olhar para fatores sociais e ambientais que atuam na determinação de grande parte das condições analisadas; mesmo quando, contraditoriamente, à medida que o conhecimento caminha, as relações entre genes, e entre genes e o ambiente, ou o social, se mostram cada vez mais complexas $^{13}$. Comportamento, inteligência, sentimento, resistência física e diferenças entre indivíduos e grupos têm sido objeto de muito investimento da pesquisa genômica. Não se tratando de condições ou doenças monogenéticas, esse tipo de pesquisa comporta, muito comumente, um viés reducionista importante.

Assim, a informação genética se constrói como uma lente poderosa em diversos sentidos: como uma lente, ela pode estar associada ao aumento da visão ou, em sentido figurado, a um modo de enfocar que transforma a percepção. A lente inovadora da genética pode, ainda, prestar-se à poderosa redução, como em dois exemplos apresentados a seguir.

O primeiro trata da "descoberta" do gene gay por Dean Hamer, em $1994^{14}$. Nesse ano, Hamer publicou Evidence for biological influence in male homosexuality, reivindicando que a orientação sexual, pelo menos em homens, teria importante componente genético. O pesquisador afirma já ter localizado pelo menos uma região (um gene) de um cromossomo (o cromossoma X) associada ao homossexualismo masculino. Após a divulgação desse resultado, sua descoberta foi imediatamente batizada como o gene gay ${ }^{15}$.

Em entrevista concedida nos Estados Unidos (Corrêa e Diniz, 2001), Hamer lembra que muitos genes da homossexualidade e da orientação sexual deverão ser ainda encontrados. "Por causa disso, acho que é um erro falar em um gene gay". James Watson, biólogo que descobriu a estrutura 
em dupla hélice do DNA em 1953, sendo atuante na pesquisa genômica ainda hoje, apontou a possibilidade de seleção pré-natal de embriões para evitar o gene da homossexualidade, ao que Hamer replica, reafirmando suas boas intenções e a necessidade de se frear impulsos de fabricar humanos de acordo com valores sociais. Ele diz não acreditar que a homossexualidade seja uma doença e que "a terapia genética deveria ser usada para curar doenças e não para modificar as pessoas no sentido de adequá-las às nossas idéias". Mas lembra, também, que as tecnologias reprodutivas, sendo usadas por homossexuais e lésbicas "podem levar não ao aborto de fetos gays, mas à criação deliberada de fetos com genes associados a esse tipo de orientação sexual". Mesmo que lhe pareça muito improvável a seleção de embriões em função da orientação sexual, o geneticista antevê, entretanto, um futuro no qual haveria interesse de pais pela seleção de crianças em função de outras características "genéticas": "se desejarem mudar algo de genético em seus filhos, eles mudarão algo como QI, habilidade para os esportes, ou mesmo estar livres de doenças. Isso tudo virá antes de uma escolha por orientação sexual."

A profissão de fé na genética e em um futuro no qual, através da informação genética, será possível selecionar e eliminar pessoas, é uma visão que se dissemina. Mesmo quando na análise do problema em pauta, fatores sociais, familiares têm um peso já bem estabelecido - nos quais o componente genético, caso exista, viria apenas se somar a estes.

O segundo exemplo é uma repetição, em um caso brasileiro, da mesma tendência. $\mathrm{O}$ protagonista agora é aquele que pode ser visto como nosso geneticista "número 1", Andrew Simpson. Simpson é responsável pelo consórcio de pesquisa que seqüenciou, pela primeira vez na história da biologia, o genoma de um fitoparasita, fato que teve enorme repercussão no meio científico internacional ${ }^{16}$. Ele coordena também o consórcio brasileiro Genoma Humano do Câncer e está envolvido, atualmente, no Projeto Genoma Clínico. Em entrevista divulgada no site da Fapesp (2000), o pesquisador louva de forma incansável os beneficios dos estudos do genoma humano e a vantagem de seus resultados ultrapassarem, em muito, questões de saúde e doença. Segundo Simpson:

“(...) a Humanidade sempre procurou se desculpar (de seus erros e deficiências) usando o destino. Então, eu estou colocando o destino na genética... Com meus filhos, também, eu não penso: meu Deus, se eu fizer isso eles serão criminosos. Eles vão ser o que eu já defini no momento em que dei 
Marilena V. Corrêa

meus genes, então posso conviver com eles e gastar meu tempo de uma maneira agradável, em vez de pensar toda hora que a minha influência vai determinar seu futuro, o que não é verdade. Dá uma liberdade para viver despreocupado. Eu acho ótimo" (Fapesp, 2000).

Se procurássemos um exemplo de atitude reducionista no pensamento do determinismo genético do comportamento, teríamos aí um caso perfeito. Por mais que se queira ver no autor dessa afirmação um tom provocativo, assim como em Hamer, quando cogita a discriminação positiva de fetos homossexuais, há que se considerar as implicações desse tipo de afirmação, mais ainda por serem veiculadas em grade escala (jornal cotidiano e internet). Se a genética pode, de fato, vir a promover redefinições do que é ser humano, ou se ela poderá completar ou modificar explicações sobre o funcionamento da mente e do corpo, é preciso que, ao se tecer considerações sobre essas questões, o contraditório, do ponto de vista biológico e de outras perspectivas, apareça de alguma maneira.

$\mathrm{O}$ enorme interesse da mídia pela biotecnologia cria questões éticas e sociais igualmente consideráveis. A mídia tem cumprido papel na celebrização de autoridades científicas e na consagração de pesquisas com resultados na maior parte das vezes ainda incipientes ou parciais (Corrêa, 1997). Biólogos em posição central no campo da genética, tanto no que diz respeito ao acesso a financiamentos, como na reprodução do conhecimento na Universidade e em papers - e que são alvo (eles e seus laboratórios) de volumosos investimentos públicos e privados - têm contribuído na difusão de uma visão parcial que reivindica a solução quase definitiva de problemas para os quais quase tudo resta ainda por ser comprovado. Essas atitudes se mostram claramente inadequadas por seu impacto social, reforçando preconceitos e atitudes discriminatórias contra indivíduos e grupos, com base em conhecimentos frágeis e questionáveis.

Um contra-exemplo é a contribuição de H. Atlan, biólogo e filósofo, que discute com freqüência as dificuldades tanto na divulgação como na própria transmissão do conhecimento genético pós-PGH, o que se reflete no debate bioético da genética hoje. Sua abordagem é um grande auxílio no combate ao problema do reducionismo, mesmo se o autor prefira isentar-se de relacionar o reducionismo a interesses e atitudes particulares dos pesquisadores. Para Atlan, o problema na transmissão da genética seria sobretudo técnico e deveria ser combatido nesse plano. Um ponto particularmente interessante é sua discussão do emprego da metáfora do programa relacionado ao DNA 
(Atlan, 1995; 1999). Entre o dado genético (genótipo) - o DNA - e sua expressão (estruturas e funções do organismo, aspecto físico do indivíduo), têm lugar mecanismos biológicos epigenéticos cuja regulação ainda é muito pouco conhecida. Esses mecanismos explicam que o mesmo gene - sem que haja mutação - possa ter expressões diferentes, em relação à função esperada. DNA (gene), RNA e proteína interagem em mecanismos complexos - genéticos e epigenéticos - de tal forma que no processamento do dado genético a maquinaria celular demonstra propriedades de aprendizado e de auto-regulação, podendo ser vista, também, como programa. O gene é, dessa forma, retroativamente regulado por mecanismos epigenéticos. Dito de outra forma, aquilo que ele produz o transforma, e o estudo dessa dinâmica celular indica capacidades auto-reguladoras. Atlan afirma, então, que "a genética não está no gene", mas talvez a meio caminho entre ele, as estruturas celulares e reações bioquímicas do metabolismo celular. O gene é mais um dado no processamento genético celular e não $o$ código, ou $o$ programa, como na metáfora informática ${ }^{17}$.

De outro ponto de vista, Holtzman (2000), geneticista da Johns Hopkins Medical Institutions, também crítico da construção social dominante da genética, afirma que ela não vai revolucionar a forma como as doenças mais comuns são identificadas e previnidas. Lembra que diferenças na estrutura social, estilos de vida e ambiente não deixaram de ser os fatores que mais contam para as desproporções no adoecimento pela maioria das doenças e que a saúde pública precisa ser melhorada, também, neste sentido. O impacto do PGH deveria, por hora, ser redimensionado, no campo da medicina, já que as doenças para as quais seus resultados podem trazer alguma contribuição diagnóstica, no médio prazo, são muito poucas. E em termos de tratamento só é possível pensar no longo prazo: os poucos experimentos com terapia genética foram frustrados ou danosos e a farmacogenômica é um campo de mera especulação.

\section{Genética e Indivíduo}

As informações genéticas individuais são obtidas através de testes genéticos. Estes identificam o genótipo relacionado a uma doença ou traço. Para as doenças monogenéticas (como a miopatia de Duchene, doença de Huntington, fibrose cística, anemia falciforme etc.), a identificação do gene ou mutação pode trazer informação relevante do ponto de vista da saúde: o sujeito terá a doença ou um risco elevado, quando a penetrância do gene não 
é completa. Mas nem mesmo para as monogenéticas, os testes apresentam uma homogeneidade em relação à probabilidade e gravidade da ocorrência das doenças - seja em função, como dito, da penetrância na expressão do gene, seja pela acuidade dos testes. Para todas as outras, doenças multifatoriais e de alta incidência (como a hipertensão arterial, diabetes), a testagem genética tem produzido, até hoje, muito mais incerteza sobre riscos do que as avaliações convencionais, em função do valor preditivo muito baixo dos testes genéticos para esse tipo de doença. Ademais, existe um enorme gap entre a possibilidade de testagem genética e as possibilidades terapêuticas. Isso gera interrogações no plano da ética, particularmente pelo fato de a informação proveniente daqueles testes implicar uma condição que passa a fazer parte da pessoa de forma permanente.

Em função do padrão familiar de ocorrência, a informação genética interfere não só na história pessoal e na identidade individual, mas também na memória das famílias. A decisão individual quanto à testagem para uma doença futura pode gerar situações de conflitos quando indivíduos, membros da mesma família, divergem quanto à vontade de conhecer seu estatuto genético.

Esse problema pode ser ainda mais agudo no caso da testagem genética pré-natal. Com o aumento das possibilidades de detecção precoce, durante a gravidez, de indicadores de risco para defeitos congênitos, ou mesmo do diagnóstico de malformações, graves dilemas se apresentam na prática do aconselhamento genético pré-natal. Cabe à mulher grávida, ou ao casal, decidir autonomamente quanto à realização de testes e exames. Dadas as limitadas possibilidades terapêuticas da medicina fetal, o aconselhamento genético pré-natal tem, hoje, um enfoque basicamente preventivo. O enfoque preventivo na gravidez em evolução é sinônimo de: seja um preparo para a recepção de um feto doente; seja, nos contextos possíveis, a eliminação, pelo aborto desse feto (Corrêa e Guilam, 2002).

As indefinições e ambigüidades resultantes dos testes e os limites das aplicações clínicas da genética contrastam com o imaginário que a caracteriza como um conhecimento extraordinário, cuja potência se refere a sua capacidade determinista e finalista: a idéia socialmente construída e difundida, de que o gene traz uma determinação final das doenças e atributos humanos.

O câncer de mama de incidência familiar é um bom exemplo. Apenas 5 a $10 \%$ dos cânceres de mama estão relacionados às mutações BRCA1 e BRCA2 identificadas, para as quais foram criados testes, como comentado. 
Estes chegam a detectar até $80 \%$ do câncer ligado àquele tipo de mutação (Fasouliotis et al., 2000). O resultado positivo, indicativo de uma maior suscetibilidade ao câncer, não garante a possibilidade de uma prevenção mais efetiva dos portadores daqueles genes: não existe, ainda, consenso médico-científico sobre a eficácia de medidas profiláticas - nem em termos cirúrgicos (mastectomia) nem clínicos - ou de rastreamento precoce para o câncer de mama (Koenig et al., 1998).

O Programa em Genética, Ética e Sociedade da Universidade de Stanford (Koenig et al., 1998), após ampla revisão sobre o assunto, indicou, por isso, que a testagem para os genes BRCA1 e BRCA2 deveria ser enquadrada como experimental e seu uso ficar restrito a contextos de pesquisa. Essa seria a forma eticamente adequada de oferta desses testes genéticos - a que mais preserva pessoas sadias com história familiar de câncer de mama, de uma possível exploração fisica, psicológica e financeira. Logo, a disponibilização comercial desses testes - divulgados e aceitos em meios médicos como grande avanço da genética - é criticável.

Outra questão eticamente relevante no impacto da informação genética para os indivíduos é a da proteção à confidencialidade dos dados genéticos. Sua não-observação fere direitos fundamentais, como o da inviolabilidade da vida privada individual, em que se insere o direito à privacidade às informações médicas e de saúde (Juengst, 1998). A forma de discriminação mais abertamente praticada, hoje, é aquela que ocorre na seleção para o trabalho e a realizada por seguradoras de saúde e de vida (Greely, 1992; Miller, 1998). O controle se torna mais abusivo quando as análises genéticas são compulsórias; ou seja, quando o candidato a um emprego ou o segurado não tem conhecimento e nem consentiu em sua realização.

A ameaça à confidencialidade também se configura na constituição de bancos de dados genéticos. O estudo genético de famílias vivendo em isolamento, ou mesmo de populações inteiras, e o cruzamento desses dados com histórias de saúde de indivíduos e suas famílias podem produzir informações muito ricas para aplicações genômicas, a serem explorados comercialmente (testes, drogas etc.). A compra de bancos de DNA por empresas de biotecnologia associadas a empresas farmacêuticas é já uma realidade. A Islândia, com uma população de 270 mil pessoas, e as Ilhas Tonga, com 108 mil, venderam bancos de DNA para as empresas deCode e Autogen, respectivamente (Greely, 2000). No caso da Islândia, por exemplo, a norma bioética do consentimento individual livre e esclarecido foi violada, uma vez que ele foi pressuposto a partir de um plebiscito no país que teve como 
vencedora a posição favorável à venda das informações genéticas e de saúde para aquelas empresas.

\section{Ética, Genética e Reprodução Humana}

O debate ético e social das implicações da pesquisa genética e biotecnológica tem seu ponto de tensão culminante nos projetos de intervenção sobre a reprodução humana. Os bebês de proveta abriram a via para a clonagem de embriões e outras pesquisas genéticas como as que visam células-tronco totipotenciais (Corrêa, 2001b). O desenho de seres humanos com vistas à longevidade, perfeição física, ou qualquer outra característica hipotética passa a ser abertamente cogitado. Pela reprodução assistida passou-se da ajuda à procriação, à fabricação de seres vivos. A duplicidade da intervenção genética novamente se coloca: 1) prevenção de doenças e ferramentas terapêuticas, como na hipótese de produção de órgãos e tecidos de reposição, a partir das células-tronco; 2) melhoria de capacidades de forma independente de riscos ou doenças, por meio de engenharia genética de embriões. Com relação à prevenção de doenças, os testes pré-natais representam a testagem genética mais antiga e mais comum. Não havendo terapia que modifique o genoma, a seleção de traços genéticos é hoje sinônimo de eliminação, não dos traços mas de seus portadores - os embriões. As implicações bioéticas desse fato traduzem-se, também, por conflitos na esfera das decisões reprodutivas dos futuros pais.

A agudização das questões éticas da genética no campo da reprodução se deve ao - até hoje justificado - temor de que a biotecnologia aporte um impulso renovado ao eugenismo e um reforço a atitudes discriminatórias contra indivíduos e grupos sociais. Da seleção de um gene de doença se passa a um traço, como sexo; da prevenção, ao melhoramento. O cenário futuro desenhado é aquele no qual capacidades físicas (estatura, força muscular), inteligência, beleza e longevidade poderiam vir a ser manipulados pela terapia/engenharia genética.

Contrapondo-se à seleção de portadores de genes de doenças, o movimento de deficientes (disability critique) afirma que essa possibilidade constitui uma atitude discriminatória contra a pessoa dos deficientes (Parens e Asch, 1999): critica-se a adoção de um modelo exclusivamente medicalizado da deficiência e a pouca escuta dessas pessoas e de sua vida, muito comumente retratada como miserável. Dever-se-ia, ainda, pensar na dificuldade das sociedades de incluir os diferentes, tanto de um ponto de vista 
material, como social e simbólico. A deficiência é uma construção sociopolítica que desaparece quando individualizada na tragédia pessoal. Definir a pessoa por sua deficiência é o elemento central na sua discriminação.

John Harris (2000) contra-ataca, mais uma vez, reivindicando que todos "geneticamente fracos" deveriam ser desencorajados da reprodução, e mesmo por medidas compulsórias. O filósofo e bioeticista argumenta que não haveria discriminação em sua proposta, uma vez que ele não faz diferença na aplicação daquelas medidas: sujeitos deficientes atuais ou pessoas normais (portadores sadios de condições de deficiência). Argumenta, ainda, que a deficiência constitui uma desvantagem e, portanto, sua proposta representaria, de fato, um benefício: proteção daqueles que (não) viriam a nascer com desvantagens - como baixa estatura, surdez (Harris, 2000) - de uma wrongful life.

O combate às doenças e desvantagens se dá em um campo no qual a genética pode voltar-se, também, para o aperfeiçoamento e melhoramento das capacidades humanas - ser mais feliz, viver mais tempo, ser mais inteligente. Essa questão implica a discussão do conceito de saúde. Com que sentido e em que bases dever-se-ia medir a saúde? Indicar o ponto até onde se tem saúde e a partir de onde se estaria indo além, no sentido de ter (mais) saúde? (Parens, 1998). Há também, para alguns bioeticistas, a defesa da neutralidade das tecnologias de melhoramento em cima do argumento de que seriam meios neutros independentes de sua aplicação (fins): uma técnica de aumento da massa muscular, por exemplo, poderia ser usada para tratar doenças degenerativas ou para aumentar a performance em competições (Walters e Gage, 1997).

A relação entre propostas eugênicas, discriminação e a biologia revela, mesmo historicamente, que a dita discriminação de base genética é, na verdade, uma discriminação ligada à construção social do essencialismo e do reducionismo genético. A imposição de diferenças socialmente hierarquizadas e atitudes discriminatórias não pode contar com um discurso genético sério. A teoria da genética molecular tem pouca contribuição, a priori, à discriminação: a idéia de normalidade/anormalidade genética é um contra-senso. Por um lado, todas as pessoas são portadoras de genes deletérios e eles não se manifestam ou se manifestam em intensidades diferentes, por mecanismos ainda muito pouco claros. Por outro lado, está bem estabelecido que a fome e a desnutrição interferem de forma dramática nas capacidades genéticas humanas. A variabilidade biológica, adaptativa ou não, mostrou-se fundamental para a manutenção da espécie, entre nós humanos, em particular 
Marilena V. Corrêa

(Azevedo, 2000). Mas a vantagem biológica da variabilidade da cor de pele, assim como a da diferença dos sexos, deu lugar aos maiores segregacionismos de que se tem conhecimento na História.

Logo, o exame bioético da genética deve ampliar-se em análises políticas da sexualidade, das normas e valores no jogo social da reprodução e da genética. Os genes gozam de uma indiferença moral e o remodelamento biológico e genético antevisto, até prova em contrário, segue padrões morais, sociais e simbólicos vigentes e dominantes. É difícil encontrarmos textos que argumentem sobre a possibilidade de nos tornarmos mais ternos e simpáticos do que competitivos. Seria possível apostar na nova genética para a reversão dessas atitudes?

Restaria, finalmente, a questão da justiça no acesso aos benefícios do mundo novo da genética. Para não falar de doenças, o aperfeiçoamento tecnológico garantido pela genética seria um bem acessível a todos? Restringir a seleção e o cruzamento genético de pessoas em função da beleza, inteligência, melhoria de performances competitivas, longevidade, a um seleto grupo, configuraria um apartheid genético ou uma biocracia? Mas apenas a garantia de acesso de todos às tecnologias de melhoramento faria delas moralmente neutras ou desejáveis?

\section{Referências Bibliográficas}

ATLAN, H. ADN: Programme ou données? (ou: la génétique n'est pas dans les gène). Bulletin of the European Society for the Philosophy of Medecine and Health Care, v. 3, n. 3, p. 1-13, 1995.

ATLAN, H. La fin du tout génétique? Vers de nouveaux paradigmes en biologie. Paris: INRA, 1999.

AZEVEDO, E. Direitos humanos e genética. Cadernos de Ética em Pesquisa, ano 3, n.,6, p. 20-23, nov. 2000.

CARNEIRO, F.; BARTHOLO Jr. R. S. O desejo de Maria. Reflexões sobre um instante de 'aconselhamento genético' em câncer de mama. In: CARNEIRO F. (org.). A moralidade dos atos científicos. Rio de Janeiro: Fiocruz, 1999. p. 125-134. 
CASSIER, M.; GAUDILLIÈRE, J-P. Le génome: bien privé ou bien commun? Biofutur 204, oct. 2000 b.

. Recherche, Médecine et marché: la génétique du cancer du sein. Sciences Sociales et Santé, v. 18, n. 4, déc. 2000a.

CASSIER, M. L'emergence de nouvelles forme d'invention collective: réseaux et consortia de recherche dans le domaine de la biotechnologie. Annales de Mines, Réalités Industriel, p 74-77, févr. 1998.

Relations entre secteurs public et privé dans la recherche sur le génome Medecine et Sciences, v. 16, n. 1, p. 26-30, janv. 2000.

COOK-DEGAN, R. M. Confidentiality, collective resources, and commercial genomics. In: ROTHSTEIN, M. A. (Ed.). Genetic Secrets: protecting privacy and confidentiality in the genetic era. New Haven: Yale University Press. 1997. p. 161-182

CORREAA, M. V.; DINIZ, D. À procura das origens sexuais. Entrevista com Dean Hamer. Correio Brasiliense, Caderno Ciência, 13 de agosto de 2001 Disponível em: http://www2.correioweb.com.br/cw/2001-08-13/ mat 49592.htm).

CORREAA, M. V. Novas tecnologias reprodutivas: Uma revolução a ser assimiliada Physis - Revista de Saúde Coletiva. Rio de Janeiro, v. 7, n. 1, p. 69-98, 1997.

Pesquisas Genéticas e Vigilância ética. Revista Eletrônica

Polêmica, n. 3; out./nov./dez. 2001. http://www2.uerj.br/ labore/ pesquisa genetica.htm

CORREAA, M. V.; GUILAM, M. C. Risk, medecine and women. A study in a genetic counselling unit in the city of Rio de Janeiro, Brasil, paper presented at XV World Congress of Sociology, Brisbane, Australia, 2002. Mimeografado.

DAVIES, K. Decifrando o genoma. A corrida para desvendar o DNA humano. Rio de Janeiro: Cia das Letras, 2001.

EISENBERG, R. S. Patent rights in the Human Genome Project. In: ANNAS, G.; ELIAS, S. (Ed.). Gene Mapping: using law and ethics as guides. Oxford: Oxford University Press, 1992. p. 226-245.

FAPESP. Entrevista com Andrew Simpson. Disponível em: http:// www.fapesp.br/encart4412.htm. Acesso em 10/04/2000.

FASOULIOTIS, S. J.; SCHENKER, J. G. BRCA1 and BRCA2 gene mutations: Decision-making dilemmas concerning testing and management. Obstetrical and Gynecological Survey, v. 55, n. 6, p. 373-384, 2000.

GELLER, G.; STRAUSS, M.; BERNHARDT, B. A.; HOLTZMAN, N. A. 
"Decoding" informed consent. Insights from women regarding breast cancer susceptibility test. Hasting Center Report, n. 27, p. 28-33, Mar./Apr. 1997. GOELEN, G.; RIGO, A.; BONDUELLE, M.; GRÈVE, J. Moral concerns of different types of patients in clinical BRCA1/2 gene mutation testing. Journal of Clinical Oncology, v. 17, n. 5, p. 1595-1600, May 1999.

GREELY, H. T. 153 Iceland's Plan for Genomics Research: facts and implications Jurimetrics Journal, v. 40, p. 153, 2000.

Health Insurance, employment discrimination, and the genetics

revolution. In: KEVLES, D.; HOOD, L. (Ed.). The code of codes: scientific and social issues in the Human Genome Project. Cambridge MA: Harvard University Press, 1992. p 264-280.

HAMER, D.; LEVAY, S. Evidence for a biological influence in male homosexuality. Scientific American, p. 44-49, May 1994.

HANSON, M. J. Religious voices in biotechnology: the case of human pateting. Hasting Center Report, v. 27, p. 1-20, Nov./Dec. 1997.

HARRIS, J. Is there a coherent social conception of disability? Journal of Medical Ethics. London, p. 1-6, April 2000.

HOGLE, L. F. Réglementer les innovations utilisant des tissus humains: hybrides et gouvernance. Sciences Sociales et Santé, v. 18, n. 4, déc. 2000. HOLTZMAN, N. A.; MARTEAU, T. M. Will genetics revolutionize medicine? New England Journal of Medecine, v. 343, n. 2, p. 141-144, July 13, 2000. JUENGST, E. T. Groups as gatekeepers to genomic research: conceptually confusing, morally hazardous, and pratically useless. Kennedy Institute of Ethics, v. 8, n. 2, p. 183-200, 1998.

JULIAN-REYNER, C.; MOATTI, J-P.; PASCALE, B.; EISINGER, F.; SOBOL, H. Vers une colonization genetique de la medecine. Sociologie et Societés, v. 28, n. 2, p. 141-155, automne 1996.

KOENIG, B. A.; GREELY, H. T.; McCONNELL, L. M. Genetic Testing for BRCA1 and BRCA2: recommendantions of the Stanford Program in Genomics, Ethics and Society et. al. Journal of Women's Health, v. 7, n. 5, p. 531-545, 1998.

LATOUR, B. La science en action. Paris: La Decouverte, 1989.

LEWIS, R. Human genetics concepts and applications. New York: MacGraw-Hill, 2001.

MCGEE, G. Gene patents can be ethical. Cambridge Quarterly of Health Care Ethics, v. 7, p. 417-421, 1998.

MERZ, J. F.; CHO, M. K. Disease genes are not patentable: a rebuttal of McGee. Cambridge Quarterly of Health Care Ethics, v. 7, p. 425-428, 1998. 
MILLER, P. S. Genetic Discrimination in the workplace. The Journal of Law, Medecine \& Ethics. Boston, v. 3, p. 189-197, Fall 1998.

OLIVEIRA, F. Uma visão feminista sobre os megaprojetos da genética humana PGH e PDGH. Bioética, v. 5, n. 2, p. 263-172, 1997.

PARENS, E.; ASCH, A. The disability rights critique of prenatal genetic testing. Reflections and Recommendations. Hasting Center Report, v. 29, n. 5, Sept./Oct. 1999.

PARENS, E. Is better always good. The Enhancement Project. Hasting Center Report, p. 1-17, Jan./Feb. 1998.

ROTHENBERG, K. H. Breast cancer, the genetic "quick fix" and the Jewish community. Ethical, legal and social challenges. Journal of LawMedicine, v. 7, n. 1, p. 97-124, 1997.

WALTERS, L., GAGE, J. The ethics of human gene therapy. New York: Oxford University Press, 1997.

\section{NOTAS}

1 Professora adjunta do Programa de Pós-graduação em Saúde Coletiva, Departamento de Políticas e Instituições de Saúde do Instituto de Medicina Social da UERJ.

2 O adjetivo "mendeliano" deriva do nome de Gregor Mendel, um monge que viveu no século XIX. Mendel realizou experimentos de cruzamento de plantas de cujos resultados deduziu leis de hereditariedade para traços e características determinadas por genes únicos. Atualmente, uma equipe da Johns Hopkins University produziu um catálogo - Mendelian Inheritance in Man (MIM) - permanentemente atualizado e que pode ser acessado em http:// www3.ncbi.nlm.nih.gov/omim/. Nesse catálogo são coletadas informações sobre doenças e características de padrão monogenético ou não (Lewis, 2001).

3 Para consultas sobre o PGH: http://www.nhgri.nih.gov/

4 Para mais informações, consultar: http://www.fapesp.br/genoma39.htm e http://www.ludwig.org.br/ ORESTES/ Com relação ao estudo de genomas não-humanos, o Brasil tem constituído outras iniciativas extremamente importantes, como a de fitoparasitas e de genoma de parasitos e outros microorganismos.

5 Conferir: http://www.nhgri.nih.gov/ELSI/

6 As características da pesquisa em consórcio e seus problemas só poderão ser discutidos, aqui, em linhas gerais. Da mesma forma, no âmbito deste artigo, não cabe entrar em detalhes sobre categorias e métodos da sociologia da inovação. Sobre isto, conferir, por exemplo, a ótima coletânea em dois volumes da revista Siences Sociales et Santé, v. 18, n. 2 e 4, 2000. 
7 Consulting Resources Corporation Newsletters citado em http://www.ornl.gov/hgmis

8 Foi o caso, por exemplo, da saída de James Watson do PGH, que voltou a dedicar-se exclusivamente ao laboratório que dirige (Cold Spring Harbour). Posteriormente, o de Craig Venter, com a criação da Celera Genomics. Casos semelhantes são muito freqüentes na pesquisa genética. O livro citado, de Kevin Davies (2001), oferece uma boa visão, em tom jornalístico, desses aspectos, dos interesses que envolvem os megaprojetos da genética, os stars cientistas e sua história recente.

9 Cassier (2000) mostra que pesquisadores do setor privado que participam de pesquisa em consórcio apresentam um taxa de citação de seus trabalhos claramente superior aos professores universitários, indicador que favorece o interesse na mobilidade dos pesquisadores para a indústria.

10 Considera-se que o pedido de patente deve mostrar: tratar-se de uma invenção (e não de uma descoberta); sua utilidade (que a invenção não é fútil) ou aplicação; e a capacidade do inventor de desenvolver o projeto. Comumente, as patentes são válidas no país em que são concedidas. Mas é possível obter patentes internacionais. Além disso, existem tratados internacionais sobre a propriedade intelectual que interferem nas leis de propriedade intelectual dos países signatários.

11 Referência faltante: Folha de São Paulo Patente perigosa 6 de abril de 2000.

12 Diante dessas dificuldades, discute-se atualmente no Comitê Internacional de Bioética da UNESCO (CIB) o interesse na criação de um organismo no sistema das Nações Unidas voltado especificamente para a questão do patenteamento e dos mecanismos de formação de preços em produtos biotecnológicos (discussão por nós presenciada em setembro de 2001 na VIII Sessão do CIB, em Paris).

13 "Genome Map Success: much yet to discover" (by Mimi Avins). Matéria publicada no Los Angeles Times, em 7 de agosto de 2000.

14 Hamer é geneticista, chefe da Seção de Estrutura e Regulação Genética do Departamento de Bioquímica do Instituto Nacional do Câncer, dos NIH, Estados Unidos, onde faz pesquisa genética há 25 anos. Há cerca de dez, voltou-se para a genética comportamental, estudando agressividade, alcoolismo, tabagismo e traços de personalidade. No último ano, seu laboratório recebeu cerca de dez milhões de dólares do Instituto Internacional de Câncer, para estudar a correlação entre genética e dependência do cigarro.

15 As pesquisas sobre genética e comportamento homossexual (como poderia ser o caso de outros comportamentos) partem de estudos de famílias que indicam que a chance de um homem se identificar como homossexual é maior, caso seu irmão gêmeo idêntico seja homossexual. A partir dessa informação, busca-se, através de técnicas moleculares, uma correlação entre seqüências de DNA (genes) e orientação sexual.

16 Trata-se da praga do amarelinho, a bactéria Xylella fastidiosa, que ataca plantações de laranja. Os resultados da pesquisa podem trazer grande benefício para a agricultura, comércio e a economia do país de um modo geral, em função da importância da agroindústria da laranja. $\mathrm{O}$ consórcio de pesquisa contou com o apoio financeiro de sindicatos ligados àquela indústria, exportadores, pesquisadores e laboratórios apoiados pela Fapesp e institutos de pesquisa privados.

17 Não é possível repetir em detalhes seus argumentos. Mas a questão, se o DNA seria gene ou programa, é discutida por Atlan (1995) em cima da própria teoria informática atual. Esta nos mostra que o sentido do programa como uma estrutura fixa - metáfora muitas vezes 
aplicada ao genoma - cai por terra a partir das análises da linguagem binária da programação informática. Aqui, programa e dados não podem ser diferenciados e podem trocar de funções, demonstrando capacidade, ambos, de lerem e de serem lidos e alterados.

\section{ABSTRACT}

\section{The Brave New Human Genome Project}

This article presents an overview of the social, ethical, and legal implications of the Human Genome Project. The benefits of this mega-project, expressed as promises of a therapeutic revolution in medicine, will not be achieved without conflict. The process of technological innovation in genetics poses problems of various orders: on the one hand, consortium-based research, gene patenting, and genomic products tend to feature commercial interests and management of the results of such research. These problems raise challenges in terms of possible inequality in access to the benefits of research. On the other hand, we have the issue of genetic information and safeguarding individual data concerning the risks and susceptibilities to human diseases and characteristics. Defining men and women as a function of genetic traits poses a clear discriminatory threat and becomes even more acute as a function of the genetic reductionism propagated by the mass media. Answers to these problems cannot be expected only from bioethics. The bioethical approach should be combined with political analyses concerning reproduction, sexuality, health, and medicine. Such a vast range of problems cannot be discussed in depth in a single article. The choice was thus made to map them in the sense of emphasizing to what extent, in reflecting on the Genome Project, genomics, and post-genomics, the challenge is met to link such diverse aspects.

Keywords: Human Genome Project; genetic innovation; reproduction; bioethics.

Recebido em: 10/12/2001.

Aprovado em: 06/03/2002. 